\title{
PENGEMBANGAN BAHAN AJAR MICRO TEACHING DALAM BENTUK BUKU BER-ISBN BAGI MAHASISWA SENI RUPA UNIVERSITAS NEGERI MEDAN
}

\author{
Adek Cerah Kurnia Azis ${ }^{*}$, Mesra $^{2 *}$, Sugito $^{3 *}$ \\ Program Studi Pendidikan Seni Rupa Jurusan Seni Rupa Fakultas Bahasa dan Seni \\ Universitas Negeri Medan \\ Jl. Willem Iskandar Pasar V Medan Estate, Kec. Percut Sei Tuan, Kab. Deli Serdang, Kode Pos 20371 \\ Sumatera Utara. Indonesia \\ Email:adek_peros@yahoo.com,mesraa121@gmail.com,sugitoas@gmail.com
}

\begin{abstract}
Abstrak
Adapun tujuan yang diharapkan dalam penelitian ini yaitu; 1). Menghasilkan bahan ajar berbasis $e$-book dan video tutorial pada Mata Kuliah Pembelajaran Micro, 2). Mengungkap validasi, praktikalitas, dan efektivitas Modul berbasis e-book dan video tutorial pada Mata Kuliah Pembelajaran Micro, 3 ). Menghasilkan sebuah publikasi Ilmiah dalam Prosiding Internasional, dan 4). Publikasi Ilmiah pada Jurnal ter-Akreditasi Sinta 4 Nasional Gorga : Jurnal Seni Rupa. Menjawab point 2 di atas, maka diperoleh nilai validasi modul berada pada pencapaian $84.25 \%$ hal ini menunjukan berada pada kategori valid, kemudian untuk nilai praktikalitas modul berada pada pencapaian $79.94 \%$ dapat dikategorikan cukup praktis dan mampu meningkatkan minat pengguna dalam proses pembelajaran, dan dilihat dari aktivitas mahasiswa masuk ke dalam kategori aktif karena berada pada persentase $79.58 \%$. Diharapkan kepada peneliti-peneliti berikutnya untuk lebih mengembangkan modul tentang Mata Kuliah Pembelajaran Micro, sehingga penelitian tersebut menghasilkan sesuatu yang lebih baru dan menjadikan mahasiswa tertarik untuk mempelajarinya, sehingga memperoleh hasil belajar yang baik terkhusus dalam proses pembelajaran dalam Mata Kuliah Pembelajaran Micro di Program Studi Pendidikan Seni Rupa Universitas Negeri Medan.
\end{abstract}

Kata Kunci: pengembangan, bahan ajar, pembelajaran micro.

\begin{abstract}
The expected objectives in this research are; 1). Produce teaching materials based on e-books and video tutorials on Micro Learning Courses, 2). Revealing the validation, practicality, and effectiveness of ebook-based modules and video tutorials in Micro Learning Courses, 3). Produce a Scientific publication in International Proceedings, and 4). Scientific Publications in the Accredited Journal of Sinta 4 Nasional Gorga: Journal of Fine Arts. Answering point 2 above, the module validation value is obtained at the achievement of $84.25 \%$, this shows that it is in the valid category, then for the practicality value of the module at $79.94 \%$, it can be categorized as quite practical and able to increase user interest in the learning process, and seen from student activity is included in the active category because it is at a percentage of $79.58 \%$. It is hoped that further researchers will further develop modules in Micro Courses, so that the research produces something newer and makes students interested in studying it, so as to obtain good learning outcomes, especially in the learning process in Micro Learning Courses in the Fine Arts Education Study Program Universitas Negeri Medan.
\end{abstract}

Keywords: development, teaching materials, micro learning.

\section{PENDAHULUAN}

Hubungan antara minat dan hasil belajar merupakan dua hal yang tidak dapat dipisahkan, sebuah minat belajar yang tinggi terhadap suatu mata kuliah atau suatu mata pelajaran akan berpegaruh terhadap sebuah hasil belajar yang baik pula. Minat yang kurang atau bisa dikatakan tidak ada sama sekali, tentunya akan berpengaruh terhadap hasil belajar yang kurang atau tidak baik pula. Bertolak dari itu semua akan ada perbedaan apabila seseorang memiliki minat atau keinginan yang lebih terhadap sebuah mata kuliah atau mata pelajaran, akan dipastikan memperoleh hasil belajar yang lebih baik pula tentunya. Ada beberapa hal yang dapat dilakukan untuk memupuk minat tersebut di atas, terkhusus dalam Mata Kuliah Pembelajaran Micro di Jurusan Seni Rupa, Fakultas Bahasa dan Seni (FBS) Universitas Negeri Medan (Unimed). Diantara hal yang dapat dilakukan yaitu dengan mengembangkan bahan ajar Mata Kuliah Pembelajaran Micro, pengembangan ini bisa dalam bentuk buku cetak, e-book berbasis android, dan video tutorial berbasis youtube, untuk 
mempermudah mahasiswa dalam mengerjakan tugastugas yang diberikan oleh seorang dosen.

Sejalan dengan perkembangan teknologi ke eramilenial sekaraang ini, ada beberapa perbedaan kebutuhan mahasiswa zaman "old" dengan mahasiswa zaman "now", dahulu dosen selalu menyuruh mahasiswa untuk menfotocopy atau membeli buku yang berhubungan dengan materi perkuliahan dengan kapasitas copyan yang cukup tebal dan dengan harga buku yang cukup mahal. Sumber informasi untuk mendapatkan buku berasar dari pasar, toko buku, pusat buku second, dimana memang harus menuju tempat penjualan buku tersebut, dan jika seorang mahasiswa tidak paham dengan membaca narasi karena tidak dapat melihat langsung prosedur atau tahapan-tahapan dalam sebuah materi perkuliahan yang harus mengikuti prosedural, namun mahasiswa tersebut hanya bisa mengimajinasikan sendiri hal tersebut, terkadang imajinasi-jinasi yang muncul justru diluar konteks materi tersebut, tentunya hal ini bisa menimbulkan kekeliruan dalam memahami materi yang ada.

Bertolak dari kemunculan-kemunculan masalah yang akan terjadi di atas, didukung dengan perkembangan teknologi dan informasi saat sekarang ini, hal yang dahulunya tidak pernah dilakukan, bisa dilaksanakan pada zaman "now" ini. Beberapa hal yang bisa dilakukan untuk meningkatkan stimulus minat belajar mahasiswa untuk mendapakan hasil belajar yang lebih baik yaitu dengan menyediakn e-book yang bisa diakses oleh mahasiswa dimanapun berada dan mahasiswa bisa membaca materi e-book tersebut dari smartphone yang mereka miliki, mahasiswa tidak perlu lagi membeli atau memfotocopy buku yang tebal dengan harga yang mahal, selanjutnya tersedianya video-video tutorial yang bisa diakses dimanapun melalui youtube dan bisa menggunakan android yang dimiliki oleh mahasiswa, hal ini justru akan lebih cepat bagi mahasiswa untuk memahami materi perkuliahan yang berhungan dengan prosedural sebuah proses pembuatan karya atau praktek mengajar.

Berdasarkan uraian tentang fenomena yang ada di atas, banyak hal yang dapat dilakukan untuk meningkatkan minat seorang mahasiswa dalam mengerjakan tugastugas yang diberikan oleh seorang dosen per-Mata Kuliahnya, diantaranya media ajar yang menarik dan media ajar yang praktis, ekonomis, dan efisien. Dilihat dari media yang dapat meningkatkan minat seorang mahasiswa untuk mendapatkan hasil belajar yang lebih baik, khususnya bagi mahasiswa Seni Rupa, salah satu stimulus yang dapat penulis lakukan dengan membuat e-book ber-International Standard Book Number
$(I S B N)$ dan video tutorial berbasis e-learning untuk bahan ajar Mata Kuliah Pembelajaran Micro yang dapat diakses, dibaca, ditonton, dan dipelajari oleh mahasiswa Seni Rupa melalui gadget, smartphone, smartwatch mereka masing-masing. Mahasiswa dapat menyimpan, men-share bahan ajar tersebut pada aplikasi Facebook (FB), WhatsApp (WA), Youtube, Email, dan lain sebagainya, yang ada pada Handphone (HP) Android yang dimiliki oleh mahasiswa tersebut, kegiatan ini dapat dilakukan oleh mahasiswa dimanapun berada, asalkan di tempat tersebut terhubung dengan network.

\section{KAJIAN TEORI}

\section{Pembelajaran Micro}

Pembelajaran Micro atau disebut juga dengan Micro Teaching merupakan suatu proses terpadu yang terbentuk dari beberapa unsur yang tugas utamanya adalah melakukan pembelajaran. Pembelajaran dan mengajar merupakan komponen yang tidak dapat dipisahkan mengajar itu mengandung secara serempak berupa unsur-unsur seperti teknologi, pengetahuan, kesenian, dan juga rasa (Azis et al, 2021: 03). Seiring dengan Seiring dengan tugas utama pembelajaran tersebut, ada beberapa keterampilan yang harus dimiliki oleh seorang pendidik: 1). Keterampilan membuka dan menutup pelajaran, 2). Keterampilan menghadapi siswa, 3). Keterampilan menggunakan metode dan media secara tepat, 4). Keterampilan mengelolah lingkungan pembelajaran, 5). Keterampilan menjelaskan pembelajaran, 6). Keterampilan bertanya, 7). Keterampilan memberikan penguatan, dan 8). Keterampilan menggunakan variasi, ( , 2013).

Dilihat dari keterampilan-keterampilan yang harus dimiliki oleh seorang pendidik, maka sebelum memiliki keterampilan tersebut sebaiknya dipahami dulu apa itu Micro Teaching. Micro Teaching atau Pembelajaran Micro adalah: "salah satu praktik mengajar alam lingkungan yang terbatas (Mikro) untuk mengembangkan dasar keterampilan mengajar (Base Teaching Learning) yang dilaksanakan secara terisolasi dalam situasi yang disederhanakan atau dikecilkan", ( , 2013). Selanjutnya Arifmiboy (2019: 53) mengungkapkan Microteaching versi TADALURING Microteaching Learning Model (TMLM) adalah model pembelajaran Microteaching yang mengkombinasikan tiga bentuk latihan atau praktek yang saling terintegrasi yaitu: classroom practice, online practice, dan offline practice. TADALURING merupakan akronim dari TA = tatap muka, DA = dalam, LU = luar, dan RING = jaringan. Sehingga TADALURING berarti tatap muka di dalam dan di luar jaringan. 
Selanjutnya Mc. Knight (dalam Syarifudin, 2014) mengungkapkan bahwa Pembelajaran Micro dapat diartikan sebagai latihan keterampilan keguruan atau praktik mengajar dalam lingkup kecil/terbatas. "Micro Teaching has been described as scaled down teaching encounter desingned to develop new skill and refine old ones", yang artinya adalah Pengajaran Micro menggambarkan kegiatan pertemuan pengajaran yang diperkecil dirancang untuk mengembangkan keterampilan baru dan memperbaiki keterampilan yang lama.

Berdasarkan penjeasan para ahli di atas maka dapat disimpulkan bahwa Pengajaran Micro merupakan kegiatan praktek mengajar kecil-kecilan atau dalam keadaan terbatas bertujuan untuk pengembangan keterampilan mengajar di depan kelas.

\section{Minat}

Minat merupakan keinginan untuk dapat memiliki sesuatu, dorongan yang ada dalam diri, mencapai sebuah yang diminati. Menurut Jersild dan Tasch (dalam Wayan 1986: 229) bahwa minat atau interest menyangkut aktifitas-aktifitas yang dipilih secara bebas oleh individu. Seseorang akan memilih yang diinginkannya sesuai dengan kehendak hatinya tanpa ada paksaan dari siapapun. Kehendak yang timbul tersebut menarik perhatian untuk dapat memiliki atau melakukannya.

Menurut Sumadi (1993: 16) mengemukakan "hal yang menarik perhatian adalah hal yang dari konteksnya" atau kalau dikatakan secara sederhana "hal yang menarik perhatian adalah hal yang lain dari lainlainnya". Kemudian Slameto (1995: 181) manjelaskan usaha pencapaian minat yaitu dapat memakai insentif dalam usaha pencapaian tujuan pengajaran. Insentif merupakan alat yang dipakai untuk membujuk seseorang agar melakukan sesuatu yang pemberian insentif akan mambangkitkan motivasi siswa dan mungkin minat terhadap bahan yang diajarkan akan muncul. Jadi, minat pada dasarnya adalah penerimaan akan suatu hubungan antara diri sendiri dengan sesuatu di luar diri (Slameto, 1995: 180).

Minat ini merupakan potensi yang dimiliki individu, merupakan sesuatu yang perlu sekali digali agar dapat diaplikasikan dengan tepat sesuai dengan bidangnya. Hal ini penting sekali diterapkan khususnya dalam rangka penentuan karir, untuk mengetahui kekuatan kelemahan kemampuan individu mahasiswa agar mahasiswa mampu memahami dirinya (pemahaman diri) terutama minat-minatnya. Dengan mengetahui secara jelas kekuatan kelemahan dirinya sendiri, individu akan mampu membuat perencanaan dan keputusan karirnya di masa depan. Selanjutnya Azis (2018: 7) mengungkapkan bahwa minat adalah suatu rasa lebih suka terhadap sesuatu yang timbul dari dalam diri (interen) dan pengaruh dari luar diri (eksteren). Minat ini timbul tanpa ada paksaan dari siapapun, merupakan kehendak dari diri sendiri, hal yang diminati merupakan sesuatu yang menarik untuk dimiliki atau dilakukan untuk karir masa depan.

Berdasarkan uraian tentang minat di atas maka dapat disimpulkan bahwa minat adalah keinginan yang timbul dari dalam diri (internal) seseorang akan ketertarikan terhadap sesuatu yang interest berasal dari luar diri (eksternal), menimbulkan keinginan untuk mendekati, mempelajari, menyentuh, dan lain sebagainya lebih dekat lagi.

\section{Hasil Belajar}

Menurut Sudjana (1987) prestasi belajar adalah kemampuan yang dimiliki oleh siswa setelah menerima pengalaman belajar, dengan demikian prestasi belajar diartikan sebagai suatu hasil atas kecakapan atau kemampuan seseorang pada bidang tertentu dalam mencapai tingkat kedewasaan yang langsung dapat diukur dengan test. Prestasi belajar merupakanpenguasaan pengetahuan atau keterampilan yang dikembangkan melalui mata pelajaran, lazimnya ditunjukkan dengan nilai tes atau angka nilai yang diberikan oleh seorang dosen (Alwi, 2002: 25). Berdasarkan uraian di atas maka dapat disimpulkan bahawa hasil belajar merupan nilai yang diperoleh seorang pserta didik setelah mengikuti pembelajaran, melaksanakan test, dalam bentuk angka atau huruf.

\section{Roadmap Penelitian}

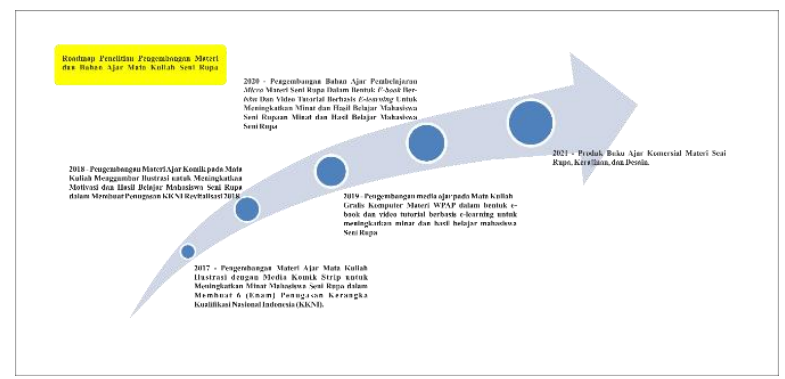

Gambar 1. Roadmap Penelitian Pengembanagan

\section{METODE PENELITIAN}

Jenis penelitian yang telah dilakukan ini masuk ke dalam penelitian pengembangan, dimana penelitian ini menghasilkan sebuah produk yang belum ada sebelumnya untuk mendukung sistem pembelajaran di Program Studi Pendidikan Seni Rupa. Pengembangan dilakukan pada Mata Kuliah Pembelajaran Micro, yang 


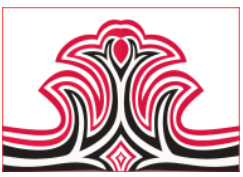

menghasilkan buku pegangan dan video tutorial Pembelajaran Micro berupa hard book dan e-book untuk Mata Kuliah Pembelajaran Micro di Jurusan Seni Rupa. Tujuan utamanya untuk meningkatkan pengetahuan, keterampilan, dan hasil belajar mengajar mahasiswa Seni Rupa selama proses perkuliahan dan ketika berada di lapangan tentunya.

\section{HASIL DAN PEMBAHASAN}

\section{Hasil}

\section{1). Tahap Desain (Design Phase)}

Penampilan kulit modul didesain sedemikian menarik, bertujuan untuk mengundang minat mahasiswa untuk mempelajari isi dari modul, dimana gambar dengan tema yang ada pada gambar/ poster selaras antara warna, huruf, penataan menjadi satu kesatuan yang untuh (Miranda, 2020: 57) . Warna, layout, tipografi, bentuk, dan ilustrasi yang ada pada kover diserasikan dengan judul, hal ini dapat dilihar pada gambar 2 berikut:

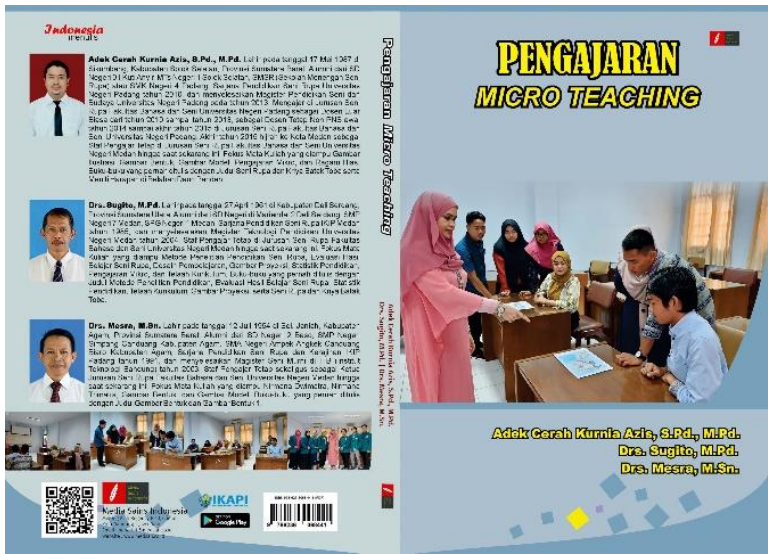

Gambar 2. Tampilan Sampul Depan Modul Pembelajaran Micro

\section{2). Tahap Pengembangan (Develop Phase)}

Tahap pengembangan meliputi validasi dan uji coba modul dan video, hal ini dilakukan untuk melihat validitas, praktikalitas, dan efektifitas modul dan video yang dikembangkan. Modul dan video yang telah disusun, selanjutnya divalidasi oleh 2 (dua) orang validator yang terdiri 1 (satu) orang ahli bidang Bahasa dan 1 (satu) orang ahli Desain. Penilaian praktikalitas dilakukan oleh mahasiswa. Modul dan video dikatakan praktis, apabila modul dan video tersebut dapat membantu mahasiswa dalam pemahaman materi dan menguasai keterampilan yang dibutuhkaan dalam Pembelajaran Micro.

\section{(1). Validasi}

Validasi ahli terdiri dari 2 (dua) tahapan yaitu, 1) memvalidasi angket lembar validasi untuk digunakan oleh validator untuk memvalidasi modul dan 2) validasi
Gorga : Jurnal Seni Rupa

Volume 10 Nomor 01 Januari-Juni 2021

p-ISSN: 2301-5942 | e-ISSN: 2580-2380

modul dengan menggunakan lembar validasi yang telah direvisi dan pemberian nilai skor pada modul. Memvalidasi angket lembar validasi bertujuan untuk menentukan dan merevisi kebutuhan yang akan dinilai dalam memvalidasi modul oleh validator. Pemvalidasian dilakukan oleh 2 (dua) orang pakar sesuai dengan bidangnya masing-masing. Berikut nama dari masing-masing validator, pada tabel 1 , berikut ini.

Tabel 1. Nama-nama Validator

\begin{tabular}{|l|l|l|}
\hline No & Nama & Bidang Keahlian \\
\hline 1. & $\begin{array}{l}\text { Frinawaty Lestarina } \\
\text { Barus, S.Pd., M.Pd. }\end{array}$ & $\begin{array}{l}\text { Pendidikan Bahasa dan } \\
\text { Sastra Indonesia }\end{array}$ \\
\hline 2. & $\begin{array}{l}\text { Drs. Gamal Kartono, } \\
\text { M.Si. }\end{array}$ & Seni Rupa (Desain Grafis) \\
\hline
\end{tabular}

Pada tahap validasi angket lembar validasi terdapat beberapa bagian yang direvisi. Hasil revisi lembar validasi masing-masing dari pakar secara umum dapat dilihat pada tabel 2, sebagai berikut ini.

Tabel 2. Hasil Revisi Lembar Validasi Masing-Masing Validator

\begin{tabular}{|c|c|}
\hline No & Keterangan \\
\hline$(1)$ & $(2)$ \\
\hline \multirow[t]{7}{*}{1.} & Frinawaty Lestarina Barus, S.Pd., M.Pd. \\
\hline & $\begin{array}{l}\text { 1. Semua istilah asing atau bahasa daerah agar } \\
\text { dimiringkan. }\end{array}$ \\
\hline & $\begin{array}{l}\text { 2. Kata yang tidak baku sebaiknya diganti } \\
\text { menjadi kata yang baku. }\end{array}$ \\
\hline & $\begin{array}{l}\text { 3. Setiap awal kalimat harus didahului dengan } \\
\text { huruf kapital. }\end{array}$ \\
\hline & Kalimat tersebut sebaiknya diubah menjadi. \\
\hline & $\begin{array}{l}\text { 5. Bahan yang diajarkan terbatas (sedikit) } \\
\text { sehingga lebih mudah untuk dikuasai dan } \\
\text { diingat. }\end{array}$ \\
\hline & $\begin{array}{l}\text { 6. Baca ulang lagi untuk meminimalisir } \\
\text { kesalahan dalam pengetikan. }\end{array}$ \\
\hline \multirow[t]{5}{*}{2.} & Drs. Gamal Kartono, M.Si. \\
\hline & $\begin{array}{l}\text { 7. } \begin{array}{l}\text { BAB IV hal } 7 \text { dan } 8 \text { poin } 6 \mathrm{~b} \text { dan } 6 \mathrm{c} \text { tida ada } \\
\text { nomornya, Bahan ajar bila guru sebagai } \\
\text { sumber utama. }\end{array} \\
\end{array}$ \\
\hline & $\begin{array}{l}\text { 8. } \\
\text { BAB IV hal } 7 \text { dan } 8 \text { poin } 6 \mathrm{~b} \text { dan } 6 \mathrm{c} \text { tida ada } \\
\text { nomornya, Bahan ajar bila guru sebagai } \\
\text { penyaji bahan ajar }\end{array}$ \\
\hline & Kata bila (hal 8) diganti dengan "apabila" \\
\hline & $\begin{array}{l}\text { 10. "Daftar Pustaka sumber dari Dirjen Dikti" } \\
\text { Cukup ditulis sekali saja pada baris pertama } \\
\text { pada baris berikutnya, diganti dengan tanda } \\
\text { saja ( } \\
\text { Dikti itu. }\end{array}$ \\
\hline
\end{tabular}

Setelah direvisi, masing-masing validator memberikan skor. Setelah masing-masing validator memberikan skor maka selanjutnya dilakukan analisis data. Hasil analisis data dapat dilihat padda tabel 3, di bawah ini.

Tabel 3. Hasil Penilaian Validator

\begin{tabular}{|l|l|c|c|}
\hline No & \multicolumn{1}{|c|}{ Variabel } & Pencapaian (\%) & Kategori \\
\hline 1. & Isi Modul & $81.5 \%$ & Valid \\
\hline 2. & Konstruksi & $75 \%$ & Cukup Valid \\
\hline 3. & Bahasa & $90.5 \%$ & Sangat Valid \\
\hline 4. & $\begin{array}{l}\text { Tampilan } \\
\text { Modul }\end{array}$ & $90 \%$ & Sangat Valid \\
\hline \multicolumn{2}{|c|}{ Rata-rata } & $84.25 \%$ & Valid \\
\hline
\end{tabular}


Hasil analisis skor penilaian validator tersebut di atas, yang terdiri dari 4 (empat) variabel menjelaskan bahwa, 1). Isi Modul berada pada pencapaian skor $81.5 \%$ masuk ke dalam kategori valid, 2). Konstruksi berada pada pencapaian $75 \%$ masuk ke dalam kategori cukup valid, 3). Variabel Bahasa berada pada $90.5 \%$ masuk ke dalam kategori sangat valid, dan 4). Tampilan modul berada pada $90 \%$ masuk ke dalam kategori sangat valid. Berdasarkan pencapaian skor di atas maka dapat diambil rata-rata dari ke-empat variabel $84.25 \%$ hasil rata-rata inipun masuk ke dalam kategori valid. Perbandingan derajat pencapaian hasil validasi modul pada masing-masng variabel yang telah dilakukan penilaian oleh validator dapat dilihat pada gambar 3, berikut ini.

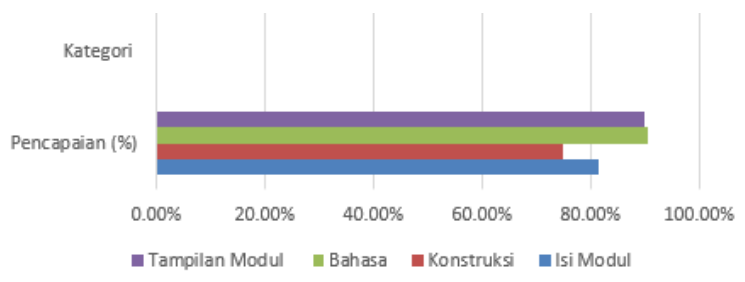

Gambar 3. Hasil Penilaian Validator

\section{(2). Praktikalitas Modul}

Praktikalitas ini dinilai oleh mahasiswa Program Studi Pendidikan Seni Rupa Jurusan Seni Rupa Fakultas Bahasa dan Seni Universitas Negeri Medan, dimana mahasiswa sekaligus sebagai objek uji coba. Setelah dilakukan penilaian, selanjutnya dilakukan analisis data. Hasil analisis data dapat dilihat pada tabel 4, berikut ini.

Tabel 4. Hasil Praktikalitas Mahasiswa

\begin{tabular}{|c|l|c|c|}
\hline No & \multicolumn{1}{|c|}{ Variabel } & $\begin{array}{c}\text { Pencapaian } \\
(\mathbf{\%})\end{array}$ & Kategori \\
\hline 1. & $\begin{array}{l}\text { Kemudahan bagi } \\
\text { Pengguna } \\
\text { (Learnability) }\end{array}$ & $81.12 \%$ & Praktis \\
\hline 2. & $\begin{array}{l}\text { Daya Guna } \\
\text { (Efficiency) }\end{array}$ & $81.2 \%$ & Praktis \\
\hline 3. & $\begin{array}{l}\text { Efektivitas Waktu } \\
\text { (Effectiveness of } \\
\text { Time) }\end{array}$ & $77.5 \%$ & Cukup Praktis \\
\hline \multicolumn{2}{|l}{ Rata-rata } & $79.94 \%$ & Cukup Praktis \\
\hline
\end{tabular}

Hasil analisis data penilaian dari mahasiswa Program Studi Pendidikan Seni Rupa Jurusan Seni Rupa Fakultas Bahasa dan Seni Universitas Negeri Medan yang sekaligus menjadi objek ujicoba modul ini, terdapat 3 (tiga) variabel, yaitu 1). Kemudahan bagi Pengguna (Learnability) dengan capaian $81.12 \%$ berasa pada kategori praktis, 2). Daya Guna (Efficiency) berada pada pencapaian $81.2 \%$ berada pada kategori praktis, dan 3). Efektivitas Waktu (Effectiveness of Time) berada pada pencapaian $77.5 \%$, hal ini menunjukkan bahwa masuk ke dalam kategori cukup praktis. Nilai rata-rata praktikalitas oleh mahasiswa dengan tingkat pecapaian $79.94 \%$ kemudian dari hasil ini dapat dikatakan bahwa modul masuk ke dalam kategori cukup praktis. Lebih jelas pencapaian praktikalitas modul oleh mahasiswa dapat dilihat pada gambar 4 , berikut ini.

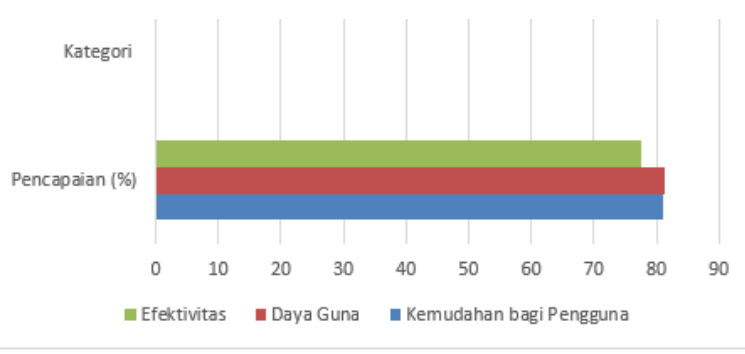

Gambar 4. Hasil Praktikalitas Mahasiswa

\section{(3). Efektivitas Modul}

Aktivitas yang dikategorikan oleh pengamat sebagai berikut: a). Membaca modul dan mengerjakan latihan; b). Memberikan pertanyaan kepada dosen yang bersangkutan disaat mengikuti proses belajar mengajar; c). Memberikan jawaban atas semua petanyaan yang diberikan oleh dosen yang bersangkutan; dan d). Mengumpulkan tugas yang diberikan oleh dosen.

Aktivitas pertama yaitu membaca modul dan mengerjakan latihan, presentasi aktivitas mahasiswa membaca modul dan mengerjakan latihan dari pertemuan pertama hingga pertemuan ke-empat berada pada $100 \%, 100 \%$, 100\%, dan $100 \%$. Dirata-ratakan $100 \%$ masuk ke dalam kategori aktif sekali. Berdasarkan hasil pengamatan mahasiswa aktif membaca modul dan mengerjakan latihan.

Aktivitas ke-dua mahasiswa mengajukan pertanyaan kepada dosen disaat mengikuti proses belajar mengajar. Persentase aktivitas dari pertemuan pertama sampai pertemuan ke-empat masing-masing sebagai berikut: $50 \%, 57 \%, 60 \%$, dan $65 \%$, dapat dirata-ratakan 58\%, maka masuk ke dalam kategori cukup aktif. Berdasarkan data di atas mahasiswa yang mengajukan pertanyaa kepada dosen pada empat pertemuan ini, mengalami peningkatan pada setiap pertemuannya. Hal ini dapat dikatakan pembelajaran menggunakan modul dapat meningkatkan hasil belajar mahasiswa.

Aktivitas ke-tiga mahasiswa menjawab pertanyaan dosen dan pertanyaan dari teman sejawat. Persentase ke-empat pertemuan ini sebagai berikut: $59.52 \%$, $57.62 \%$, 61.43\%, dan $62.86 \%$, maka dapat dirataratakan $60.35 \%$. Hal ini dapat dikategorikan kepada mahasiswa cukup aktif. Berdasarkan data persentase di atas, dapat dikatakan bahwa mahasiswa mengalami 


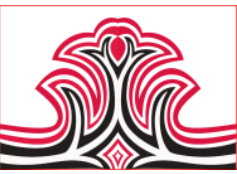

peningkatan dari pertemuan pertama hingga pertemuan ke-empat dalam menjawab pertanyaan dari dosen dan teman sejawatnya.

Aktivitas ke-empat menyelesikan tugas yang diberikan oleh dosen. Semua mahasiswa mengumpulkan tugastugasnya dari pertemuan pertama hingga pertemuan keempat dimana persentase untuk masing-masing pertemuannya sebagai berikut: $100 \%, 100 \%, 100 \%$, dan $100 \%$, dengan rata-rata aktivitas mahasiswa $100 \%$, maka dapat dikategorikan mahasiswanya aktif sekali. Tugas-tugas yang diberikan harus diselesaikan oleh masing-masing individu, maka setiap mahasiswa memiliki tanggungjawab atas tugas-tugas yang diberikan oleh dosen. Rata-rata aktivitas mahasiswa di atas dari masing-masing kategori dapat dilihat secara umum pada dilihat secara umum pada tabel 5 , berikut ini.

Tabel 5. Hasil Persentase Pencapaian Aktivitas Mahasiswa

\begin{tabular}{|c|c|c|c|}
\hline No & $\begin{array}{c}\text { Kategori Aktivitas } \\
\text { Mahasiswa }\end{array}$ & $\begin{array}{c}\text { Persentase } \\
(\%)\end{array}$ & Kriteria \\
\hline 1. & $\begin{array}{l}\text { Membaca modul dan } \\
\text { mengerjakan latihan. }\end{array}$ & 100 & $\begin{array}{c}\text { Aktif } \\
\text { Sekali }\end{array}$ \\
\hline 2. & $\begin{array}{l}\text { Memberikan pertanyaan } \\
\text { kepada dosen. }\end{array}$ & 58 & $\begin{array}{l}\text { Cukup } \\
\text { Aktif }\end{array}$ \\
\hline 3. & $\begin{array}{l}\text { Memberikan jawaban } \\
\text { atas semua pertanyaan } \\
\text { yang diberikan oleh } \\
\text { dosen dan teman } \\
\text { sejawat. }\end{array}$ & 60.35 & $\begin{array}{l}\text { Cukup } \\
\text { Aktif }\end{array}$ \\
\hline 4. & $\begin{array}{l}\text { Mengumpulkan tugas } \\
\text { yang diberikan oleh } \\
\text { dosen. }\end{array}$ & 100 & $\begin{array}{l}\text { Aktif } \\
\text { Sekali }\end{array}$ \\
\hline & $\begin{array}{c}\text { Rata-rata Secara } \\
\text { Keseluruahn }\end{array}$ & 79.58 & Aktif \\
\hline
\end{tabular}

Berdasarkan hasil analisis aktivitas mahasiswa selama proses pembelajaran dengan tingkat pencapaian persentase $79.58 \%$ masuk ke dalam kategori mahasiswa aktif. Untuk melihat perbandingan hal tersebut di atas dapat dilihat pada gambar 5, berikut ini.

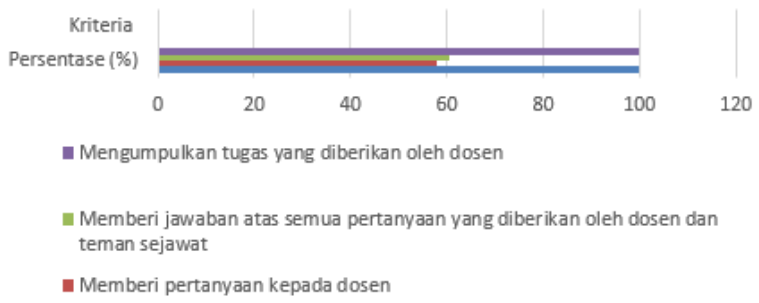

Gambar 5. Hasil Persentase Pencapaian Aktivitas Mahasiswa

\section{Pembahasan}

Berdasarkan uraian hasil penilaian validator, praktikalitas mahasiswa, dan pecapaian aktivitas mahasiswa, maka dapat diuraikan sebagai berikut: 1). Isi Modul, Konstruksi, Bahasa, dan Tampilan Modul
Gorga : Jurnal Seni Rupa

Volume 10 Nomor 01 Januari-Juni 2021

p-ISSN: 2301-5942 | e-ISSN: 2580-2380

berada pada pencapaian $84.25 \%$ hal ini menunjukkan bahwa modul berada pada kategori valid. Uraian isi pada modul disusun secara sistematis, hal ini memudahkan pengguna dalam memahami modul. Modul dirumuskan dalam satu unit pembelajaran yang diawali dengan penyajian materi dan evaluasi. Penyajian modul sesuai dengan tingkat kemampuan mahasiswa. Menurut Depdiknas (2008a:3-5) sebuah modul dikatakan baik dan mudah dipahami mahasiswa jika materi dalam satu unit yang utuh sesuai dengan kemampuan pengguna (Self Contained).

Kemudahan bagi pengguna (Learnability) modul yaitu dosen sebagai pembimbing dalam proses pembelajaran dengan nilai $81,12 \%$ berada pada kategori praktis bagi pengguna. Dimana modul memiliki petunjuk, bahasa yang sesuai dengan karakteristik mahasiswa, dapat digunakan perorangan, dan latihan yang ada dalam modul dapat membantu dosen dalam memberikan arahan kepada mahasiswa untuk memahami konsep. Tujuan merancang modul adalah mempermudah dosen dalam membimbing dan mengarahkan mahasiswa dalam proses pembelajaran micro.

Daya guna modul bagi mahasiswa (Efficiency) dengan pencapaian nilai $81,12 \%$ masuk ke dalam kategori praktis. Modul dapat membantu mahasiswa dalam menerangkan konsep. Diharapkan juga mampu membantu dosen mengarahkan mahasiswa dalam proses pembelajaran. "salah satu dari tujuan modul adalah memperjelas dan mempermudah penyajian pesan agar tidak terlalu bersifat verbal (Depdiknas, 2008b:5-6).

Kepraktisan dan efektivitas waktu (Effectiveness of Time) berada pada kategori cukup praktis dengan nilai pencapaian 77,5\%. Modul dikembangkan secara praktis digunakan oleh dosen untuk membimbing mahasiswa dalam proses pembelajaran. Dosen dapat memanfaatkan waktu yang minimal dengan hasil belajar yang maksimal. Menurut Depdiknas (2008b:5) modul yang baik dapat mengatasi keterbatasan waktu, ruang, dan daya indera, bagi mahasiswa dalam proses pembelajaran.

Hasil evaluasi belajar mahasiswa dapat dinyatakan lulus sebanyak 15 orang. Persentase mahasiswa yang lulus $100 \%$. Tujuan evaluasi untuk menentukan apakah mahasiswa yang diajar sudah memiliki kompetensi yang telah ditetapkan sehingga layak diberikan materi pembelajaran berikutnya.

Kepraktisan modul membuktikan bahwa, 15 orang mahasiswa yang menggunakan modul dalam proses 


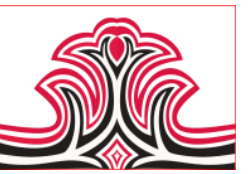

pembelajaran, $100 \%$ mahasiswa dinyatakan tuntas. Selanjutnya, berdasarkan pengamatan yang diamati oleh satu orang pengamat, umumnya mahasiswa aktif dalam proses pembelajaran. Hal ini menunjukkan bahwa modul sangat praktis dan efektif digunakan dalam proses pembelajaran dan dapat meningkaatkan minat mahasiswa dalam proses belajar mengajar.

\section{KESIMPULAN DAN SARAN}

\section{Kesimpulan}

Berdasarkan uraian data dan pembahasan di atas dapat disimpulkan sebagai berikut: 1). Telah dihasilkan modul Mata Kuliah Pembelajaran Micro untuk peningkatan pengetahuan, keterampilan mengajar, minat, dan hasil belajar mahasiswa selama proses belajar mengajar di kampus ataupun di sekolah nantinya, dan 2). Nilai validitas modul berada pada pencapaian $84,25 \%$ berada pada kategori valid. Nilai praktikalitas modul oleh mahasiswa berada pada tingkat pencapaian $79,94 \%$ dapat dikategorikan cukup praktis dan mampu meningkatkan minat pengguna dalam proses pembelajaran, dan untuk aktivitas mahasiswa masuk ke dalam kategori aktif karena berada pada persentase $79.58 \%$.

\section{Saran}

Diharapkan kepada peneliti-peneliti berikutnya untuk lebih mengembangkan modul tentang Mata Kuliah Pembelajaran Micro, sehingga penelitian tersebut menghasilkan sesuatu yang lebih baru dan menjadikan mahasiswa tertarik untuk mempelajarinya, sehingga memperoleh hasil belajar yang baik terkhusus dalam proses pembelajaran dalam Mata Kuliah Pembelajaran Micro di Program Studi Pendidikan Seni Rupa Universitas Negeri Medan.

\section{DAFTAR RUJUKAN}

. (2013). Pembelajaran Mikro (Micro

Teaching).https://fayezfeztiawan.wordpress.c om/2013/03/01/pembelajaran-mikro-microteaching/ (diakses tanggal 05 Mei 2020).

Azis, A. C. K., Sugito, M. P., \& Mesra, M. S. (2021). Pengajaran Micro Teaching. Media Sains Indonesia. https://books.google.co.id/books?hl=id $\& 1 \mathrm{r}=\&$ id=4LEhEAAAQBAJ\&oi=fnd \&pg=PA149\& $\mathrm{dq}=$ Pengajaran + Micro + Teaching \&ots $=3 \mathrm{IbDz}$ kMRzA\&sig=PQ1vXgMkZ2M_CcI90rQIgx $\mathrm{bHrAY} \&$ redir_esc $=\mathrm{y} \# \mathrm{v}=$ onepage $\& \mathrm{q}=$ Pengaj aran\%20Micro\%20Teaching $\& \mathrm{f}=$ false.

Alwi Hasan dkk. (2002). Kamus Besar Bahasa Indonesia. Jakarta: Balai Pustaka.

Arifmiboy. (2019). Microteaching Model TADALURING. Ponorogo: Wade Group.
Gorga : Jurnal Seni Rupa

Volume 10 Nomor 01 Januari-Juni 2021

p-ISSN: 2301-5942 | e-ISSN: 2580-2380

Azis, A. C. K. (2018). Pengembangan Materi Ajar Komik pada Mata Kuliah Menggambar Ilustrasi untuk Meningkatkan Motivasi dan Hasil Belajar Mahasiswa Seni Rupa dalam Membuat Penugasan KKNI Revitalisasi 2018. Laporan Akhir Penelitian tidak di terbitkan. Medan: LPPM Unimed.

Miranda, A., \& Azis, A. C. K. (2020). Analisis Media Poster Capres Prabowo Sandi Dalam Kampanye Pilpres Tahun 2019. MAVIS: Jurnal Desain Komunikasi Visual, 2(2), 5557. https://doi.org/10.32664/mavis.v2i2.470

Slameto. (2003). Belajar dan Faktor-Faktor yang Mempengaruhinya. Jakarta: Rineka Cipta.

Sumadi, Suryabrata. (2002). Pengertian Minat. Jakarta:

Sudjana, Nana. (1987). Dasar-Dasar Belajar Mengajar. Bandung : Sinar Baru.

Syarifudin, Andri. (2014). Pengertian Pembelajaran Micro.http://andrisyarifudin2.blogspot.com/2 014/06/pengertian-pembelajaran-micro.html (diakses tanggal 05 Mei 2020).

Wayan, Nurkancana. (1986). Evaluasi Pendidikan. Surabaya: Usaha Nasional. 